\title{
Microbiological Induced Corrosion on Brass in Recycling Cooling Water System Makeup by Reclaimed Water
}

\author{
Ping $\mathrm{Xu}^{1,2}$, Zhaoyi $\mathrm{Xu}^{1}$, Jin Wang ${ }^{1}$, Yajun Zhang ${ }^{2}$, Ting Liu ${ }^{2}$ \\ ${ }^{1}$ School of Civil Engineering and Architecture, Beijing Jiaotong University, Beijing, China; ${ }^{2}$ Key Laboratory of Urban Stormwater \\ System and Water Environment, Beijing University of Civil Engineering and Architecture, Ministry of Education, Beijing, China. \\ Email: xuping@bucea.edu.cn
}

Received January $18^{\text {th }}, 2012$; revised February $27^{\text {th }}, 2012$; accepted March $29^{\text {th }}, 2012$

\begin{abstract}
The impacts of microorganism on brass corrosion were studied in static experiment in this paper. Two main factors, temperature and concentration ratio, were considered. According to the actual operation of recycling cooling water system, four temperatures $\left(15^{\circ} \mathrm{C}, 25^{\circ} \mathrm{C}, 35^{\circ} \mathrm{C}\right.$ and $\left.45^{\circ} \mathrm{C}\right)$ and four concentration ratios $(1,2.5,3.5$ and 4.5$)$ were selected in the experiment. Corrosion potential, current density, average corrosion rate were measured by time. The results showed that: microorganism often aggravated corrosion of brass during initial and final stages, but alleviated its corrosion at the middle time. With the extension of time that brass immersed in the solution, the microbes began to intensify the corrosion of the metal. When concentration ratios were 2.5 and 3.5 and temperature was $15^{\circ} \mathrm{C}$, microbe promoted brass corrosion obviously and corrosion degrees.
\end{abstract}

Keywords: Reclaimed Water; Brass; Microbiologically Induced Corrosion; Corrosion Potential; Corrosion Current Density; Average Corrosion Ratio; Temperature; Concentration Ratio

\section{Introduction}

Almost every surface can be colonized by bacteria, forming biofilms [1]. The corrosion due to existence or action of the microorganisms in biofilm is called microbiologically-influenced corrosion (MIC). Many metals are sensible to MIC. Pitting, crevice corrosion, hydrogen embrittlement and deposit corrosion caused by MIC almost involve all kinds of fields, such as petrochemical industry, aviation, shipping, powder industry and so on [2-6]. According to statistics, MIC accounted for $20 \%$ in metal and building materials corrosion damages [7]. The direct economic loss by MIC is about 300 to 500 billion dollars [8].

Because of serious water shortage in some big cities in China, such as Beijing, Tianjin, Dalian and so on, it is a feasible method to reuse reclaimed water to cooling water system of power plant. However, there are full of nutrients in reclaimed water and the temperature is high in recycling cooling water system. These conditions are beneficial to microorganisms growing on metal surfaces. A variety of microorganisms and their metabolic reaction

\footnotetext{
${ }^{*}$ The paper is supported by two Chinese national grand projects for water pollution control: Integrative Technology and Demonstration on Reclaimed Water Utilized to Industry in Beijing (2009ZX07314-00904); Research Technology of and Demonstration on Urban Water Conservation (2009ZX07317-005).
}

products may promote the deterioration of the underlying substratum. For ultimately biocorrosion control, it is firstly needed to understand the impacts of microorganism on metal corrosion. Brass is widely used in condenser of cooling water system of power plants in China. The impacts of microorganism on brass corrosion were studied by electrochemical method and mass loss method in this paper. Two main factors, temperature and concentration ratio, were considered.

\section{Materials and Method}

\subsection{Electrochemical Method}

Shanghai Chen Hua CHI660C electrochemical workstation was used for experiment. Its scanning speed was $0.01 \mathrm{~V} / \mathrm{s}$ and the sensitivity was $10^{-4} \mathrm{~A} / \mathrm{V} . \mathrm{Ag} /(\mathrm{AgCl}) /$ $\mathrm{KCl}(0.1 \mathrm{~mol} / \mathrm{L})$ was selected as reference electrode and platinum was as counter electrode.

During experiment, cross-sectional area of HSn70-1A brass was $1 \mathrm{~cm}^{2}$. Its main chemical compositions was shown as following (Wt\%): $\mathrm{Pb} \leq 0.05, \mathrm{Fe} \leq 0.10, \mathrm{Sb} \leq$ $0.005, \mathrm{P} \leq 0.01, \mathrm{Bi} \leq 0.002$, Sn $0.8-1.3$, As $0.03-0.06$, $\mathrm{Cu} 69.0$ - 71.0, $\mathrm{Zn}$ little.

In electrochemical experiment, corrosion potential and current density could be got by Tafel curves, which were obtained by dynamic potential scanning method Corro- 
sion potential reflects corrosion tendency or degree and corrosion current density shows corrosion rate. More negative corrosion potential means that metal is more vulnerable to corrosion. Higer current density reflects the faster corrosion rate of metal.

\subsection{Mass Loss Method}

Type I (50 mm $\times 25 \mathrm{~mm} \times 2 \mathrm{~mm}) \mathrm{HSn} 70-1 \mathrm{~A}$ brass coupons were selected for the experiment. Average corrosion rate of a brass coupon could be calculated by the formula as follows:

$$
X=\frac{87600 \cdot\left(m-m_{0}\right)}{s \cdot t \cdot \rho}
$$

where $X$-average brass corrosion rate, $\mathrm{mm} / \mathrm{a}$; $m$-mass loss of a brass coupon in experiment, $\mathrm{g}$; $m_{0}$-mass loss of a brass coupon in blank test, $\mathrm{g}$; $s$-surface area of a brass coupon, $\mathrm{cm}^{2}$; $\rho$-density of a brass coupon, $\mathrm{g} \cdot \mathrm{cm}^{-3}$; $t$-test time, h.

\subsection{Reclaimed Water}

Reclaimed water was obtained from a makeup pipe of a cooling water system of a thermal power plant in Beijing. Table 1 showed the quality of reclaimed water in the experiment.

\subsection{Experiment Arrangement}

Two main factors, temperature and concentration ratio, were considered in static experiment. According to the actual operation of recycling cooling water system, four temperatures $\left(15^{\circ} \mathrm{C}, 25^{\circ} \mathrm{C}, 35^{\circ} \mathrm{C}\right.$ and $\left.45^{\circ} \mathrm{C}\right)$ and four concentration ratios $(1,2.5,3.5$ and 4.5$)$ were selected in the experiment. For obtaining microbial influences on brass

Table 1. Reclaimed water in a thermal power plant in Beijing.

\begin{tabular}{|c|c|c|c|c|}
\hline Item & $\mathrm{pH}$ & $\begin{array}{c}\text { Conductivity } \\
\text { us } / \mathrm{cm}\end{array}$ & $\begin{array}{c}\text { Total } \\
\text { hardness } \\
\mathrm{mg} / \mathrm{L}\end{array}$ & $\begin{array}{l}\text { Alkalinity } \\
\mathrm{mmol} / \mathrm{L}\end{array}$ \\
\hline Value & 7.53 & 1134 & 248 & 3.2 \\
\hline Item & $\begin{array}{l}\text { Iron } \\
\mathrm{ug} / \mathrm{L}\end{array}$ & $\begin{array}{l}\text { Turbidity } \\
\text { NTU }\end{array}$ & $\begin{array}{c}\mathrm{Cl}^{-} \\
\mathrm{mg} / \mathrm{L}\end{array}$ & $\begin{array}{l}\mathrm{COD} \\
\mathrm{mg} / \mathrm{L}\end{array}$ \\
\hline Value & 157.9 & 9.1 & 111.3 & 5.0 \\
\hline Item & $\begin{array}{c}\mathrm{TP} \\
\mathrm{mg} / \mathrm{L}\end{array}$ & $\begin{array}{c}\mathrm{NH}_{4}-\mathrm{N} \\
\mathrm{mg} / \mathrm{L}\end{array}$ & $\begin{array}{l}\mathrm{SO}_{4}^{2-} \\
\mathrm{mg} / \mathrm{L}\end{array}$ & $\begin{array}{c}\mathrm{SS} \\
\mathrm{mg} / \mathrm{L}\end{array}$ \\
\hline Value & 0.9 & 1.0 & 114.4 & 5 \\
\hline Item & \multicolumn{2}{|c|}{$\begin{array}{l}\text { Total dissolved solids } \\
\mathrm{mg} / \mathrm{L}\end{array}$} & $\begin{array}{l}\mathrm{HPC} \\
\mathrm{cfu} / \mathrm{ml}\end{array}$ & \\
\hline Value & \multicolumn{2}{|c|}{534} & $2 \times 10^{4}$ & \\
\hline
\end{tabular}

corrosion, experiments were operated in reclaimed water with bacteria and reclaimed water without bacteria. Reclaimed water with bacteria was directly obtained from the make-up system of circulating cooling system of a thermal power plant in Beijing. Reclaimed water without bacteria could be got after disinfection in a high pressure steam sterilizer with $121^{\circ} \mathrm{C} \pm 1{ }^{\circ} \mathrm{C}$ temperature for 20 minutes.

\section{Results and Discussion}

\subsection{Microbiological Induced Corrosion on Brass in Different Temperatures}

\subsubsection{Corrosion Potential}

Corrosion potentials in reclaimed water with or without bacteria in different temperatures were shown in Figure 1.

According to Figure 1, corrosion potentials of brass in $15^{\circ} \mathrm{C}$ reclaimed water with bacteria are more negative than the values in bacteria free water from start to finish, existence of microorganism worsened the corrosion obviously. Under other temperatures, compared with reclaimed water without bacteria, corrosion potentials in one with bacteria were more negative at the beginning and last time, but less negative at the middle stage. That means that microorganism aggravated corrosion of brass during initial and final stages, but alleviated the corrosion tendency at the middle time. At the early time, biofilm had not fully formed yet. Uneven covering layer resulted more serious corrosion. With the growth of biofilm, more uniform and deeper layer retarded the tendency of corrosion. At the same time, formation of biofilm hindered corrosive ions from arriving at the surface of brass. Adult biofilm had stable ecosystem. More serious corrosion would be caused by metabolic reactions or deposition.

Moreover, compared with corrosion potentials in $15^{\circ} \mathrm{C}$, $25^{\circ} \mathrm{C}, 45^{\circ} \mathrm{C}$, values in $35^{\circ} \mathrm{C}$ were all most negative whenever in reclaimed water with bacteria or not.

\subsubsection{Corrosion Current Density}

Corrosion current density in reclaimed water with or without bacteria in different temperatures were shown in Figure 2.

According to Figure 2, both in reclaimed water with or without bacteria, current densities were also higher at higher temperatures. That means corrosion rates of brass in higher environment were faster than the values in lower temperature.

Moreover, compared with current densities in $25^{\circ} \mathrm{C}$, $35^{\circ} \mathrm{C}$ and $45^{\circ} \mathrm{C}$ reclaimed water with bacteria or not, current densities in one with bacteria were higher at the beginning and last stages and lower at middle stage. The lowest densities in reclaimed water with bacteria occurred on the third or fifth day. Current densities in the 


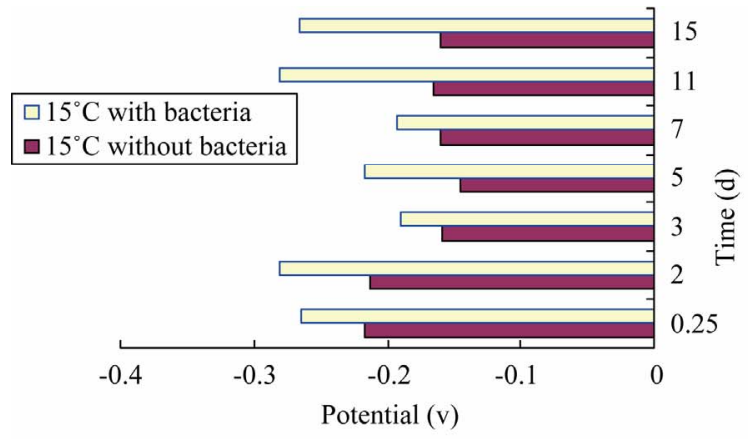

(a)

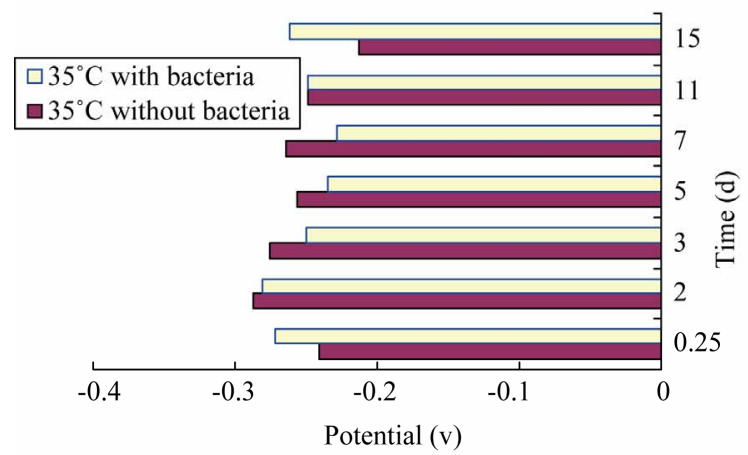

(c)

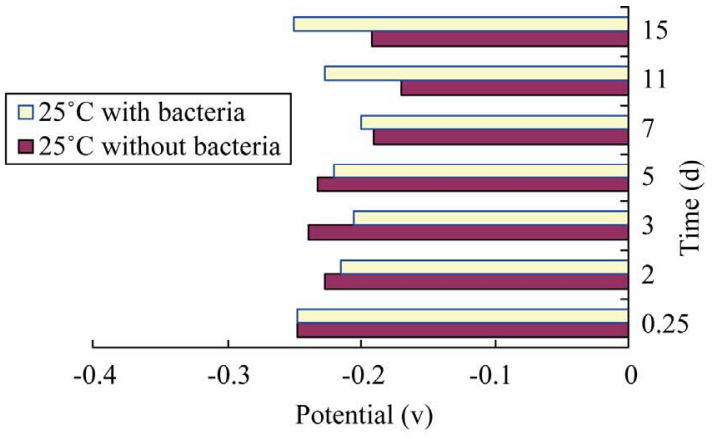

(b)

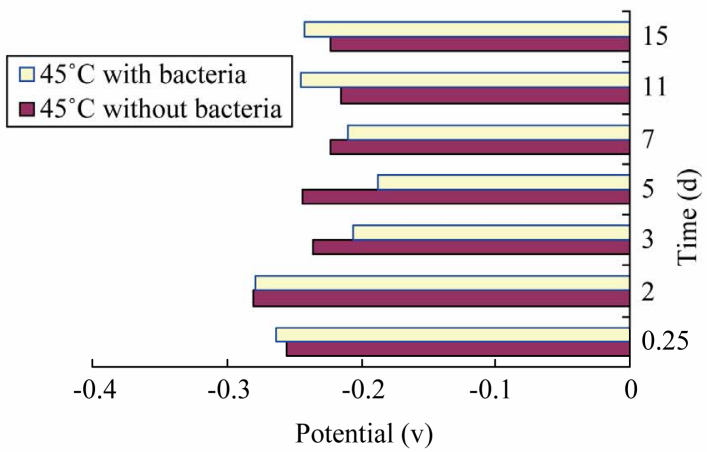

(d)

Figure 1. Corrosion potentials in reclaimed water with or without bacteria in different temperatures. (a) $15^{\circ} \mathrm{C}$; (b) $25^{\circ} \mathrm{C}$; (c) $35^{\circ} \mathrm{C}$; (d) $45^{\circ} \mathrm{C}$.

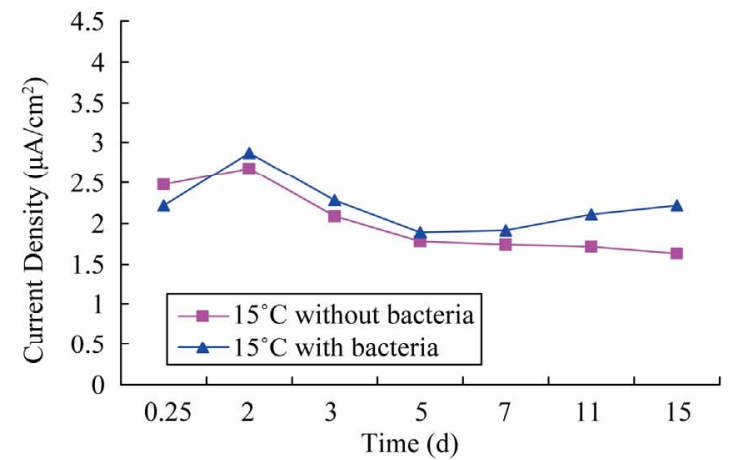

(a)

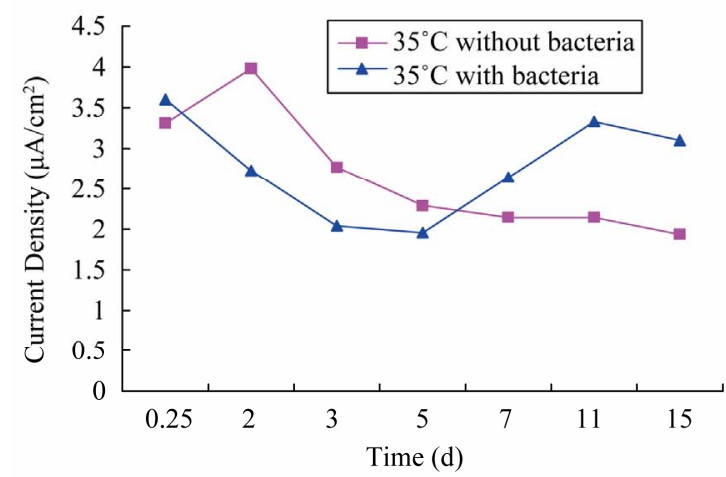

(c)

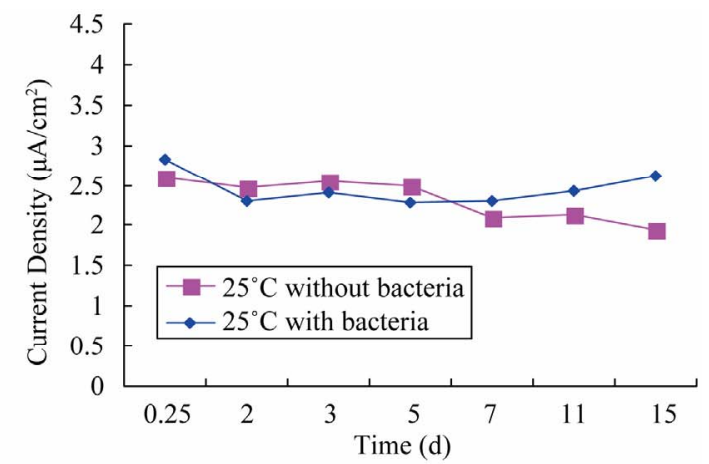

(b)

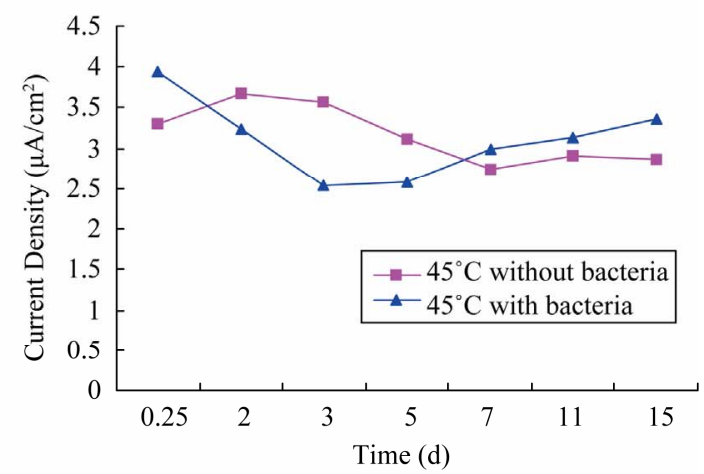

(d)

Figure 2. Corrosion current density in reclaimed water with or without bacteria in different temperatures. (a) $15^{\circ} \mathrm{C}$; (b) $25^{\circ} \mathrm{C}$; (c) $35^{\circ} \mathrm{C}$; (d) $45^{\circ} \mathrm{C}$. 
water with bacteria began to exceed the values in bacteria free one after fifth day. In the initial stages of brass immersed in reclaimed water, maybe on first day, the presence of microorganisms would accelerate the corrosion rate. Then with the biofilm on the surface of brass mature gradually, it prevented corrosion ions from contacting with the metal, so corrosion rates decreased at these stages. After that period, corrosion rates in reclaimed water began to increase and ultimately exacerbate corrosion rates of brass. Maybe uneven biofilm on the surface caused serious corrosion of the metal.

\subsubsection{Average Corrosion Rate}

Average corrosion rates of couples in reclaimed water with or without bacteria in different temperatures were shown in Figure 3.

According to Figure 3, the developments of average corrosions in different temperatures were similar to the results of electrochemical experiments. In $25^{\circ} \mathrm{C}, 35^{\circ} \mathrm{C}$ and $45^{\circ} \mathrm{C}$ reclaimed with bacteria, compared with average corrosions in bacteria free reclaimed water, at first stage, often within one or two days, corrosions of brass were higher. Then the corrosions began to decrease and were lower than the values in bacteria free one. For a long time, often more than 9 days, average corrosions in reclaimed water with bacteria began to increase and ultimately were higher than values in bacteria free one. Moreover, average corrosion rates in $35^{\circ} \mathrm{C}$ and $45^{\circ} \mathrm{C}$ were higher than the rates in $15^{\circ} \mathrm{C}$ and $25^{\circ} \mathrm{C}$. The faster values occurred in $35^{\circ} \mathrm{C}$ and the lowest one occurred in $15^{\circ} \mathrm{C}$. The results further proved that the corrosion of brass would be effected by micro-organisms. For a long time, corrosion rates in reclaimed water with bacteria would be faster than ones in bacteria free reclaimed water.

\subsection{Microbiological Induced Corrosion on Brass in Different Concentration Ratio}

\subsubsection{Corrosion Potential}

Corrosion potentials in reclaimed water with or without bacteria in different concentration ratios were shown in Figure 4.

Based on Figure 4, both in reclaimed water with or without bacteria, corrosion potentials were more negative at higher concentration ratios. That means increasing concentration ratios would aggravate the corrosion tendency of brass in reclaimed water. There were high concentrated ions and nutrient substances under higher ratios, which were beneficial to corrosion development and caused more serious corrosion.

In four ratios, corrosion potentials in reclaimed water with bacteria were more negative than values in bacteria free one when concentration ratios were 2.5 and 3.5.
Under these conditions, the roles of the microbe to promote corrosion were more obvious and corrosion degrees of brass in reclaimed water with bacteria were more serious. When concentration ratios were 1 and 4.5, corrosion potentials in reclaimed water with bacteria were more positive than values in bacteria free one within 10 days. After that, corrosion potentials in reclaimed water with bacteria move to negative direction and aggravated the brass corrosion.

\subsubsection{Corrosion Current Density}

Corrosion current density in reclaimed water with or without bacteria in different concentration ratios were shown in Figure 5.

Based on Figure 5, both in reclaimed water with or without bacteria, corrosion current densities were also higher at higher concentration ratios. That means increasing concentration ratios would faster the corrosion of brass in reclaimed water. High concentrated ions and nutrient substances promoted corrosion development and caused more serious corrosion.

Compared with two curves of reclaimed water with bacterial and without bacterial in Figure 5, corrosion current densities of without bacterial one decreased with the time growth, but corrosion current densities of with bacterial one decreased at initial stage and then increased at second stage. The lowest point occurred at fifth or sixth day at ratio of 1 and 2.5. When concentration ratio was up to 3.5 and 4.5 , the lowest point had been put off, often at $10^{\text {th }}$ day. With the extension of time that brass immersed in the solution, the microbes began to intensify the corrosion of the metal.

\section{Conclusions}

In a conclusion, whenever in reclaimed water with bacteria or not, most serious corrosion occurred at $35^{\circ} \mathrm{C}$ and increasing concentration ratios would aggravate the corrosion tendency of brass.

Microorganism often aggravated corrosion of brass during initial and final stages, but alleviated its corrosion at the middle time. With the extension of time that brass immersed in the solution, the microbes began to intensify the corrosion of the metal. When concentration ratios were 2.5 and 3.5 and temperature was $15^{\circ} \mathrm{C}$, microbe promoted brass corrosion obviously and corrosion degrees in reclaimed water with bacteria were more serious.

\section{Acknowledgements}

The research was supported by two Chinese national grand projects for water pollution control: Integrative Technology and Demonstration on Reclaimed Water Utilized to Industry in Beijing (2009ZX07314-009-04); Research Technology of and Demonstration on Urban 


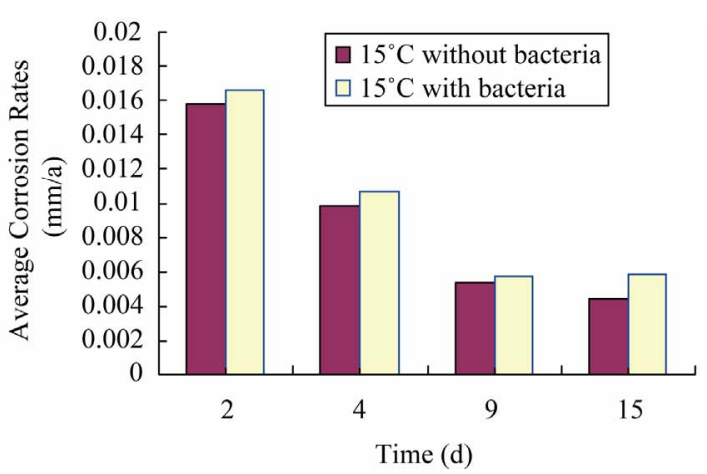

(a)

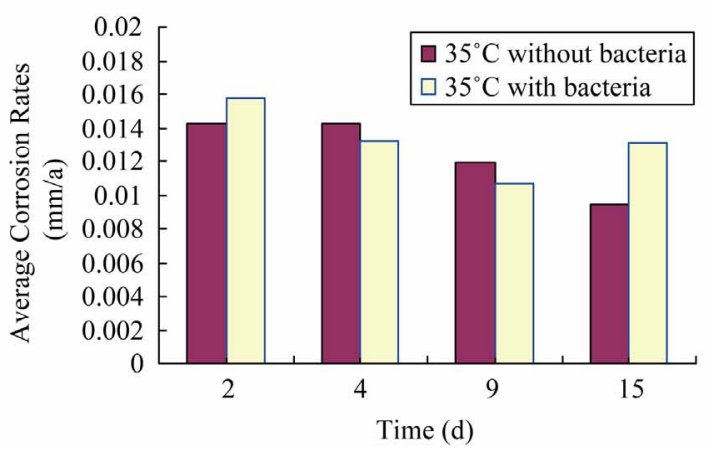

(c)

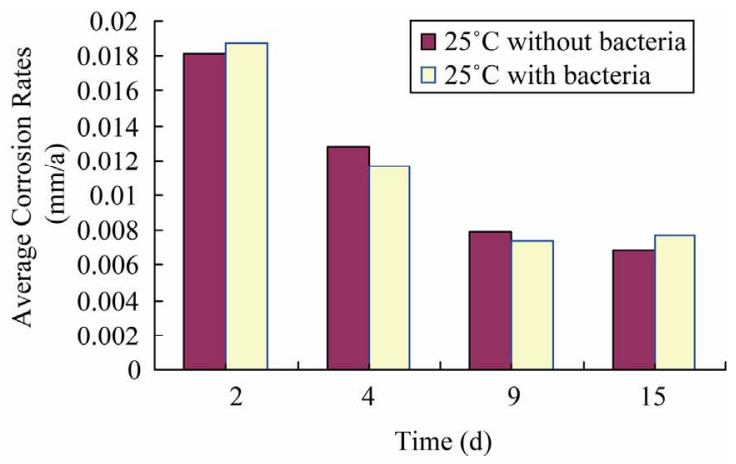

(b)

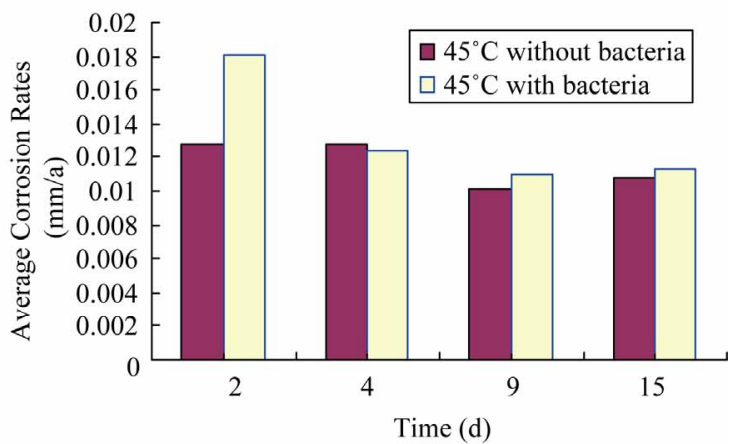

(d)

Figure 3. Average corrosion rates of couples in reclaimed water with or without bacteria in different temperatures. (a) $15^{\circ} \mathrm{C}$; (b) $25^{\circ} \mathrm{C}$; (c) $35^{\circ} \mathrm{C}$; (d) $45^{\circ} \mathrm{C}$.

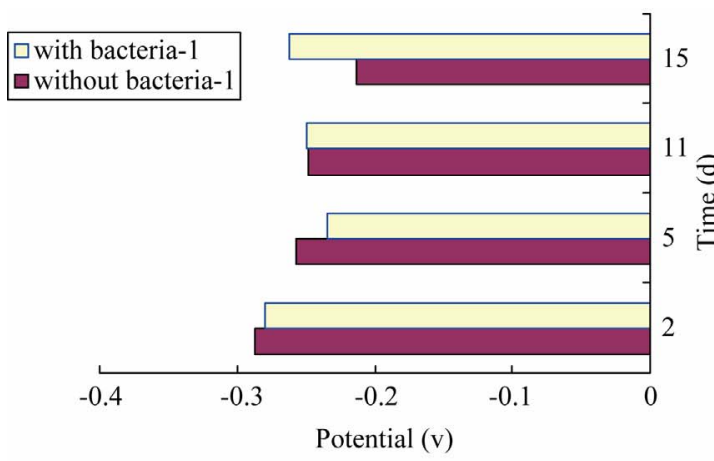

(a)

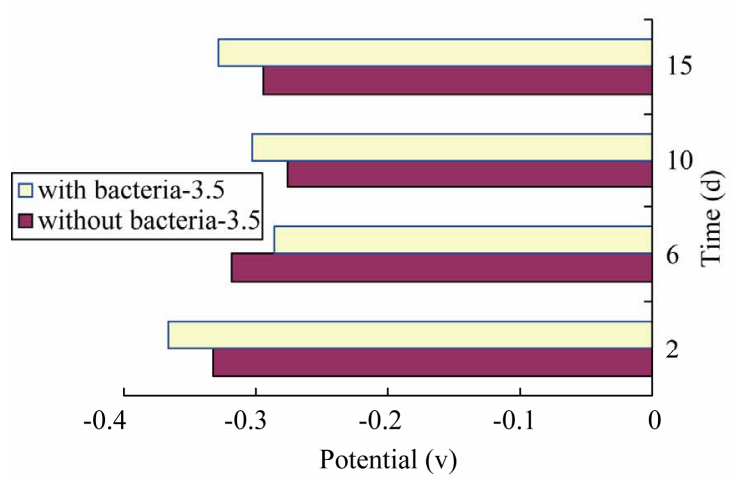

(c)

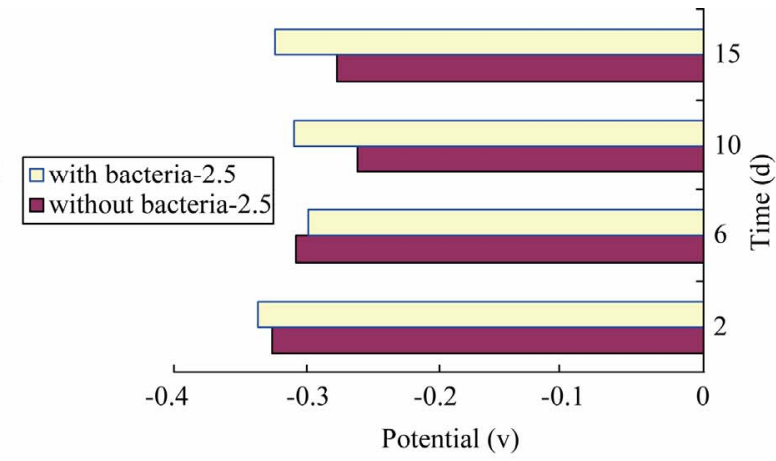

(b)

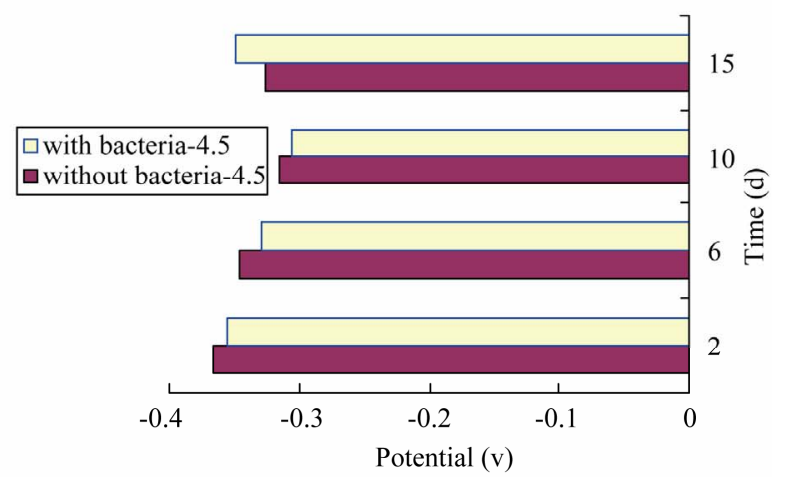

(d)

Figure 4. Corrosion potentials in reclaimed water with or without bacteria in different concentration ratios. (a) Ratio-1; (b) Ratio-2.5; (c) Ratio-3.5; (d) Ratio-4.5. 


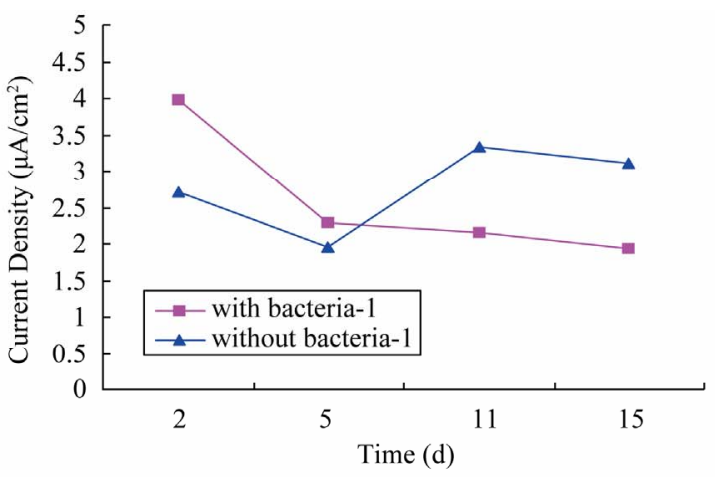

(a)

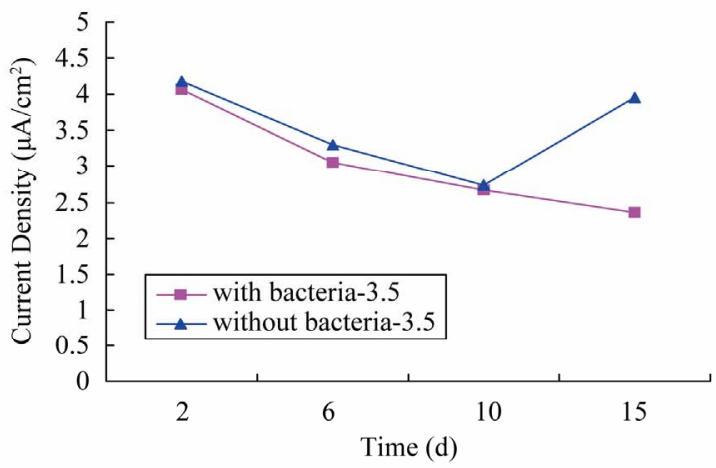

(c)

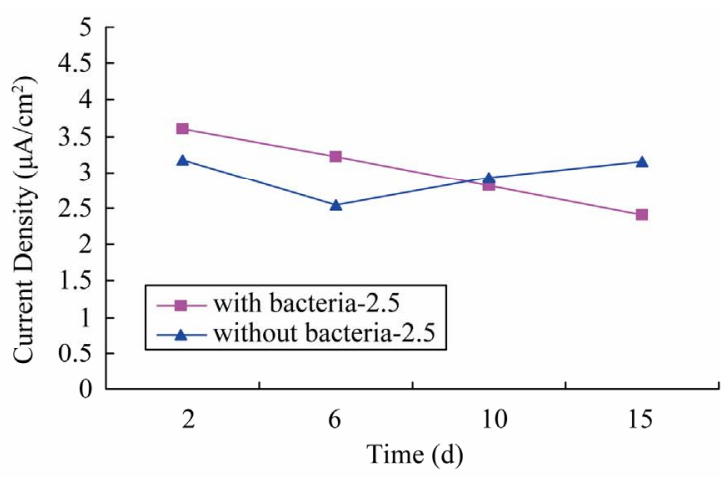

(b)

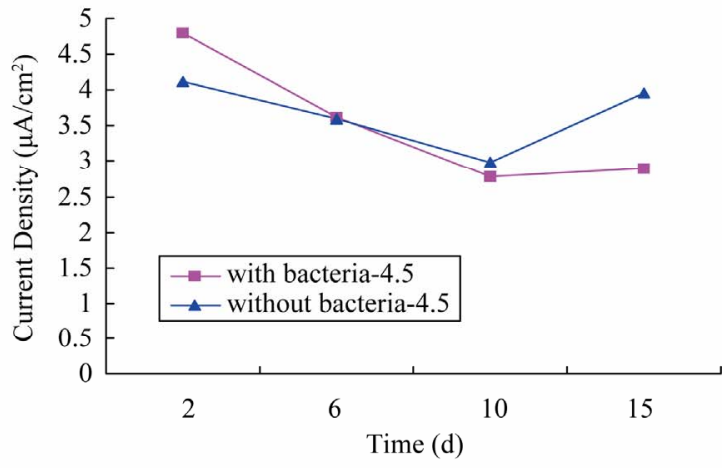

(d)

Figure 5. Corrosion current density in reclaimed water with or without bacteria in different concentration ratios. (a) Ratio-1; (b) Ratio-2.5; (c) Ratio-3.5; (d) Ratio-4.5.

Water-Conservation (2009ZX07317-005). Moreover, the paper was also supported by Key Laboratory of Urban Stormwater System and Water Environment of Beijing University of Civil Engineering and Architecture of Ministry of Education.

\section{REFERENCES}

[1] H.-C. Flemming, "Why Microorganisms Live in Biofilms and the Problem of Biofouling," In: J. William Costerton, Springer Series on Biofilms, Volume 4 Marine and Industrial Biofouling, Springer-Verlag, Berlin Heidelberg, 2009, pp. 3-11.

[2] W. A. Hamilton, "Sulfate Reducing Bacteria and Anaerobic Corrosion," Annual Review of Microbiology, Vol. 39, 1985, pp. 195-217. doi:10.1146/annurev.mi.39.100185.001211

[3] H. C. Flemming, "Biofouling and Microbiologically Influenced Corrosion (MIC) - An Economical and Technical Overview," In: E. Heitz, W. Sand and H. C. Flemming,
Microbial Deterioration of Material, Springer, Heidelberg, 1996, pp. 5-14.

[4] M. B. Mcnecil and B. J. Litter, "Mackinawite Formation during Microbial Corrosion," Corrosion, Vol. 46, No. 7, 1990, pp. 599-601. doi:10.5006/1.3585154

[5] A. M. EI Din Shams, T. M. H. Saber and A. A. Hammoud, "Biofilm Formation on Stainless Steels in Arabian Gulf Water," Desalination, Vol. 107, No. 3, 1996, pp. 251-264. doi:10.1016/S0011-9164(96)00167-1

[6] E. Heitz and W. Sand, "Microbial Influenced Corrosion of Material," Springer-Verlag, Berlin, 1996, pp. 82-86. doi:10.1007/978-3-642-80017-7

[7] H. C. Flemming, "Economical and Technical Overview," In: Microbially Influenced Corrosion of Materials, SpringerVerlag, Heidelberg, 1996.

[8] D. Walsh, D. Pope, M. Danford, et al., "The Effect of Microstructure on Microbiologically Influenced Corrosion," Journal of Management, Vol. 45, No. 9, 1993, pp. 22-30. doi:10.1007/BF03222429 